
\title{
ZS Research Square \\ The ring of truth: Irrelevant insights make worldviews seem true
}

Ruben Laukkonen ( $\square$ ruben.laukkonen@gmail.com )

Vrije Universiteit Amsterdam

\section{Benjamin Kaveladze}

University of California, Irvine, USA

John Protzko

University of California, Santa Barbara https://orcid.org/0000-0001-5710-8635

Jason Tangen

The University of Queensland

William von Hippel

University of Queensland

Jonathan Schooler

Keywords:

Posted Date: May 24th, 2021

DOI: https://doi.org/10.21203/rs.3.rs-547655/v1

License: (c) (1) This work is licensed under a Creative Commons Attribution 4.0 International License.

Read Full License 


\section{Abstract}

The authors have requested that this preprint be removed from Research Square. 